\title{
O manuscrito e a manualidade como resistência e diferenciação
}

Gisela Belluzzo de Campos desenvolve pesquisas em design gráfico e arte contemporânea, com foco nas linguagens gráfica e visual. É Doutora e Mestre em Comunicação e Semiótica pela Pontifícia Universidade Católica de São Paulo (PUC-SP) e professora titular do Programa de Pós-Graduação em Design da Universidade Anhembi Morumbi (São Paulo).

camposbelluzzo@gmail.com ORCID 0000-0002-5743-1093
Resumo Este texto traz impressões e comentários sobre uma visita a 34ª Bienal de São Paulo, ocorrida entre setembro e dezembro de 2021, com a marca da decolonialidade. A exposição mostrou-se surpreendente pela quantidade de escritos, cartas e relatos manuscritos, bem como de imagens manualmente realizadas. Estas obras contrastam com o excesso de imagens técnicas que inundam nosso cotidiano e nos fazem conhecer e sentir a força de produções compostas com escritas e desenhos, com marcas autorais significativas, as quais revelam modos de vida que resistem aos preceitos da dominação e da globalização em aspectos políticos, sociais e artísticos.

Palavras-chave Manualidade, Decolonialidade, $34^{\mathrm{a}}$ Bienal de São Paulo. 


\section{The manuscript and manuality as resistance and differentiation}

Abstract this text brings impressions and comments on a visit to the 34th Bienal de São Paulo, which took place between September and December 2021, with the mark of decoloniality. The exhibition showed to be surprising due to the amount of handwritten writings, letters, and reports, as well as hand-crafted images. These works contrast with the excess of technical images that flood our daily lives and make us know and feel the strength of productions composed with writings and drawings, with significant authorship marks, which reveal ways of life that resist the precepts of domination and globalization in political, social and artistic aspects.

Keywords manuality, decoloniality, 34th Bienal de São Paulo.

\section{El manuscrito y la manualidad como resistencia y diferenciación}

Resumen Este texto trae impresiones y comentarios sobre uma visita a la $34^{\underline{a}}$ Bienal de São Paulo, que tuvo lugar entre septiembre y diciembre de 2021, com el sello de la descolonialidad. La exposición resultó sorpreendente por la cantidad de escritos, cartas e informes escritos a mano, así como por imágenes artesanales. Estas obras constrastan com el excesso de imágenes técnicas que inundan nuestro día a día y nos hacen conocer y sentir la fuerza de producciones compuestos de escritos y dibujos, com importantes marcas de autor, que revelan formas de vida que resisten los preceptos de dominación y globalización em aspectos políticos, sociales y artísticos.

Palabras clave manualidad, decolonialidad, $34^{\underline{a}}$ Bienal de São Paulo. 


\section{Introdução}

Em visita à $34^{\mathrm{a}}$ Bienal de São Paulo, ocorrida entre setembro e dezembro de 2021, com a marca do decolonialismo, foi surpreendente ver a quantidade de escritos, cartas e relatos, sobretudo manuscritos, presentes na exposição, em muitos casos, acompanhadas de imagens feitas a mão. Diante desses trabalhos foi inevitável fazer um paralelo com a questão das imagens técnicas tal como Flusser (2008) e Cardoso (2012) apontam, ao discorrerem, respectivamente, sobre a imagem e a internet, e ambos, sobre a superfície enquanto deslizamento incessante de imagens presentes em nosso cotidiano.

De acordo com o texto no website, a mostra teve o verso do poeta amazonense Thiago de Mello, Faz escuro mas eu canto, como mote com a intenção de reivindicar "a necessidade da arte como um campo de resistência, ruptura e transformação" (34ª Bienal de São Paulo, 2021). E, de fato, desde que a mostra começou a ser concebida até sua inauguração com um ano de atraso devido à pandemia do Covid-19, eventos trágicos como desastres com refugiados, incêndios na Amazonia, invasões de terra, perseguição a povos indígenas e número de mortos pelo corona vírus, se intensificaram e a discussão e a formação de grupos tidos como " minoritários" como indígenas, feministas, antirracistas e LGBTQIA+, aumentaram e de alguma forma se fortaleceram, apesar de, e talvez até estimulados, pelos intensos movimentos de forças direitistas contrárias, no Brasil e no mundo. A proposta da Mostra é dar voz a manifestações de arte pouco ouvidas, conforme discussão do corpo curatorial.

Como dito acima, nesta mostra, destaca-se a forte presença de obras realizadas manualmente, sobretudo escritas e desenhos, em detrimento de imagens técnicas. Essa presença é notada mais ainda em contraste com o momento em que uma grande parte da população vive uma forte relação com a tecnologia, relação esta, nem sempre feliz, devido às restrições impostas pela pandemia, a qual trouxe à tona, de modo ainda mais acentuado do que já acontecia antes, o trabalho mediado pela internet e por redes sociais como o WhatsApp, o entretenimento e a informação por meio de lives de todos os tipos intensificando a vida permeada pela tecnologia digital como um todo.

Assim, estas obras têm um impacto até maior nesse momento do que em outros, por terem sido feitas distantes desta tecnologia onipresente, onipotente e onisciente, e, muitas vezes, por grupos que não tem acesso, frequente ou nenhum, a estas ferramentas ou que privilegiam outras formas e outras técnicas, para expressar sua arte, tais como indígenas brasileiros e africanos.

Flusser (2008), já assinalava, em meados da década de 1980, a inundação de imagens técnicas, naquele momento protagonizadas pela televisão e pela fotografia, mas já prevendo a sua intensificação com as imagens digitais que estavam em seus primórdios, do ponto de vista massivo. No prefácio de seu livro $O$ universo das imagens técnicas, coloca que a socie- 
dade sintetizada pelas imagens técnicas "[...] será uma sociedade estranha radicalmente diferente da nossa (FLUSSER, 2008, p.7)."

Cardoso (2012), aponta a inundação de imagens disponíveis na internet, sem uma ordenação lógica ou compreensível e o estado de indiferenciação que isso provoca, fazendo com que as imagens percam sua referência tornando-se opacas.

[...] na web não é nada clara a distinção entre meio, superfície e referência. Tudo vira uma coisa só, porquanto a paisagem visual se move à volta do observador. Por conta dessa indistinção entre o que é fixo e o que é móvel, o que é figura e o que é fundo, o que é significante e o que é significado, os objetos virtuais adquirem extraordinária fluidez de sentido (CARDOSO, 2012, p. 214).

O autor denomina de lógica de visualidade errática" essa indiferenciação das imagens favorecida pelos tratamentos e manipulações digitais, reforçada pelo modo como imagem e texto aparecem correlacionados pelos mecanismos de busca. Nesta indiferenciação e indistinção, o público e o privado também se mesclam e se confundem, perdendo-se a dimensão do singular e do gesto.

\section{Obras}

Entre as obras, ressalto alguns trabalhos, nos quais se destacam as escritas, as caligrafias, as cartas e os desenhos manuais.

A primeira delas é instalação Corte/Relação montada pela curadora e pesquisadora brasileira Ana Kiffer que traz cadernos, cartas e textos manuscritos de Antonin Artaud (1896-1948) e de Édouard Glissant (1928-2011). Diz a pesquisadora: "A arquitetura imaginária de Corte/Relação, "[...] teve início em 2018, quando pesquisava os arquivos de Glissant recém-chegados ao acervo da Biblioteca Nacional Francesa" (KIFFER, 2021, p.253). Segundo Kiffer, Glissant, poeta, escritor, romancista, ensaísta e teatrólogo francês nascido na Martinica, planejava editar uma revista literária e cultural chamada Baton Rouge em cujo primeiro número teria um texto de abertura, inédito, de Artaud. Essa ideia rascunhada em uma carta encontrada pela pesquisadora, nunca se realizou, mas a fez fabular um encontro geopolítico que também nunca aconteceu.

Por meio de cadernos e escritos, recheados de rascunhos e desenhos, a curadora aproximou os dois autores, que na realidade nunca tiveram contato. Uniu os dois poetas que, segundo ela, fizeram travessias inversas, mas com propósitos semelhantes - a procura da relação com o outro. Artaud partiu da França em direção ao México, em busca da civilização Tarahumara e Glissant da Martinica para Paris.

Kiffer aponta a ligação entre "corpo da escrita" e corpo das experiências" e de como os poetas vão construindo seus pensamentos por meio da 
gestualidade de suas escritas transformando esses cadernos em um "modo vivo de pensar e de escrever o mundo".

Glissant diz que escreve sempre a mão, e diz que acredita que quem escreve primeiro no computador "diz o que todo mundo diz". o corpo, deixando de ser uma matéria passiva diante da atividade do pensamento-escrita, torna-se ativo e abre-se ao que ali se tece e se constrói, sendo ele também modificado nesse processo. É esta zona processual, aqui e ali indiscernível, entre corpo e a escrita que faz com que olhar para "objetos" tão precários quanto cotidianos, como os cadernos, nos permita um outro modo de conceber a escrita e os corpos em nossa sociedade [...]" (KIFFER 2021, p.254).

Figura 1 . Édouard Glissant. Brésil, s.d.

Manuscritos (fac-símiles)

Fonte: $34^{a}$ Bienal de São Paulo

Foto: Gisela Belluzzo

Figura 2. Édouard Glissant.

Página do caderno A viagem ao Nilo s/d

Fac-símile

Fonte: $34^{\mathrm{a}}$ Bienal de São Paulo

Foto: Gisela Belluzzo
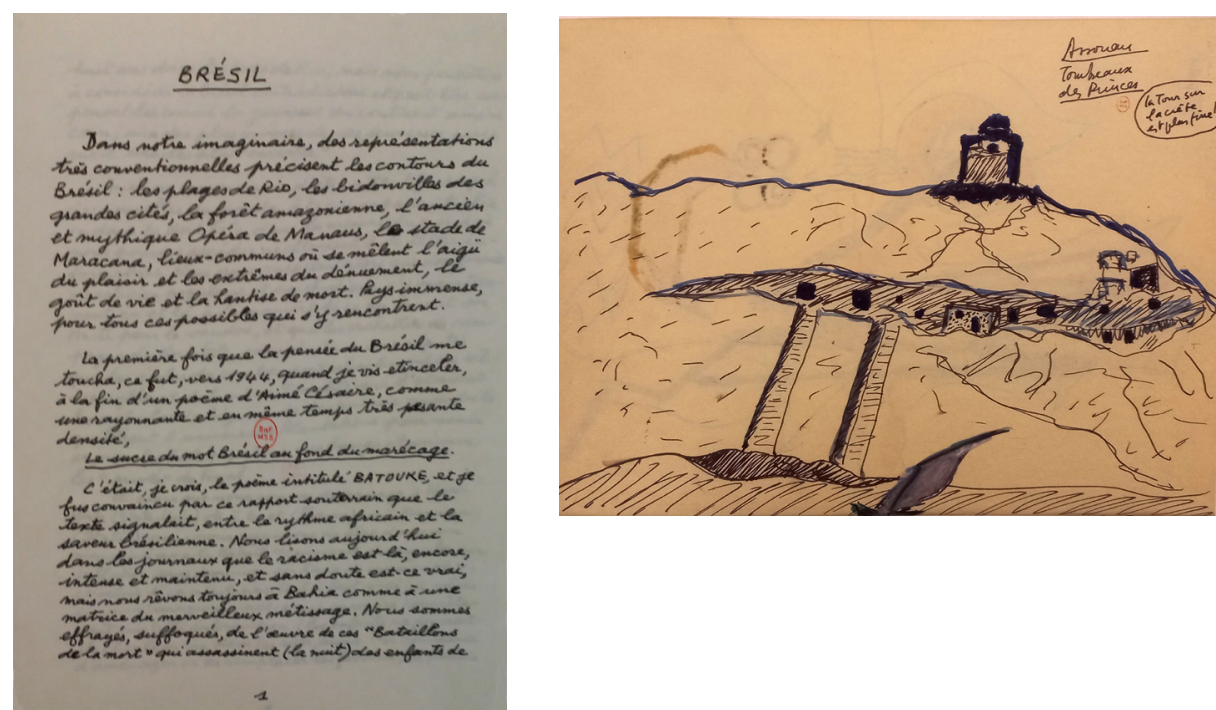

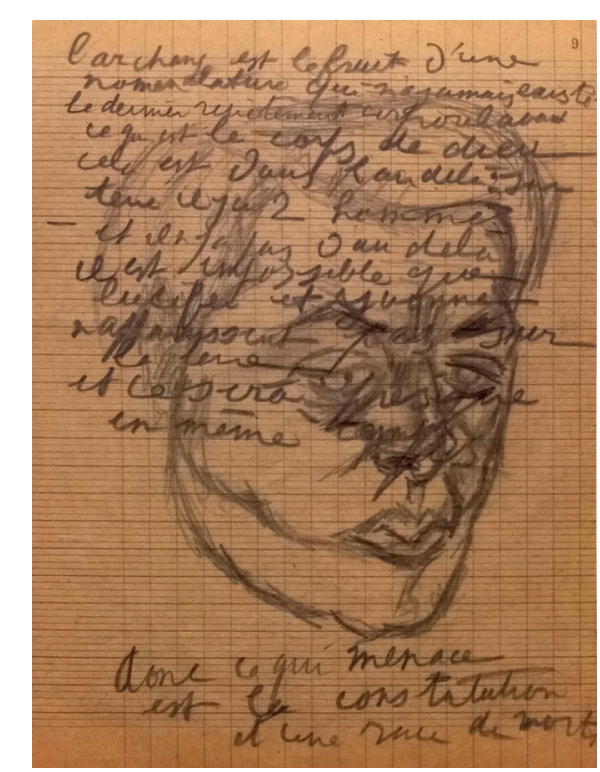

Figura 3. Antonin Artaud.Página do caderno 253

1947. Autorretrato com faca e notas. (Fac-símile)

Fonte: $34^{a}$ Bienal de São Paulo Foto: Gisela Belluzzo

Figura 4. Antonin Artaud. Pagina do caderno 351, 1947.

Retrato de homem e notas. FacSímile

Fonte: $34^{\mathrm{a}}$ Bienal de São Paulo Foto: Gisela Belluzzo

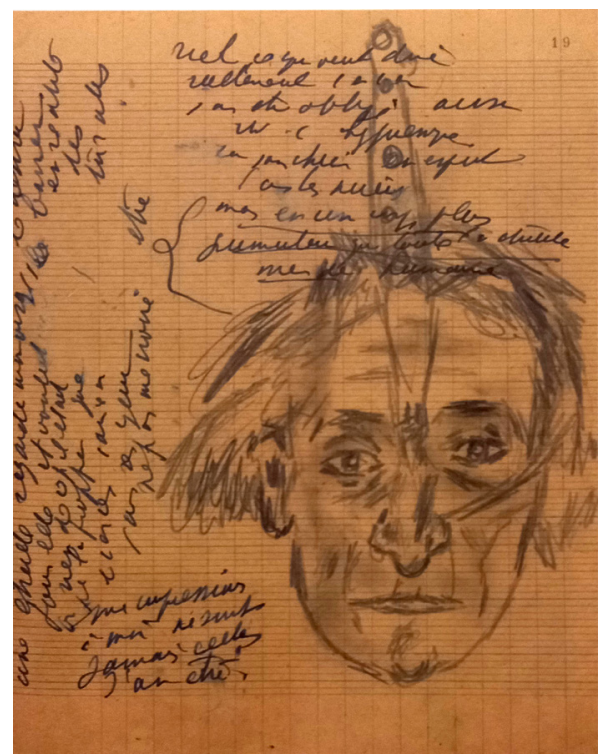


Em outro trecho, a curadora escreve sobre os cadernos dos dois poetas: "Escrita- gesto que trafega entre o desenho e o texto, mas sobretudo que indica a presença do traço como força de relação da escrita com tudo que apartamos do mundo letrado (KIFFER, 2021, p.254)". Essa última citação vem ampliar o conceito de escrita, abri-la para o gesto, para a expressão, não apenas em seu conteúdo, mas também em sua forma.

Um segundo corpo de obras a ser apontado na mostra é a série Obra sem título 2008-2012 de Paulo Kapela, artista angolano, nascido em 1947 e falecido em 2020. De acordo com os curadores em textos de parede da exposição, Paulo Kapela era um mestre artístico e espiritual e sua obra é imbuída de forte sincretismo com referências ao catolicismo, à filosofia bantu e ao rastafarianismo. Na Bienal são apresentadas colagens manuais, com imagens, desenhos, pequenos objetos e escritos justapostos, cobertos de textos referentes a pessoas conhecidas, amigos e histórias pessoais. $\mathrm{O}$ artista é referência por seu trabalho de grande força expressiva, que retrata esforço em reescrever a história colonial de Angola em busca de uma "crioulização" entre elementos de dominação ocidental e a realidade política, cultural e social, local.

Kapela representou Angola na 52 ${ }^{\mathrm{a}}$ Bienal de Veneza, em 2007, e seu trabalho é considerado, por muitos, um ponto importante no contexto da reconciliação entre as culturas europeia e africana, bem como uma lembrança de uma sociedade fragmentada e ferida após os anos de guerra. Toda a sua produção artística conjuga o passado e o presente de sua vida pessoal e de Angola. Ele é capaz de recriar histórias paralelas à oficial por meio de uma perspectiva única, combinando narrativas reais e fantásticas e, assim, relatar os pesadelos e utopias de Luanda. (GERMANO, 2020).

Figura 5 . Paulo Kapela, sem título, 2008-2012

Técnica mista

Fonte: $34^{a}$ Bienal de São Paulo Foto: Gisela Belluzzo

Figura 6. Paulo Kapela, sem título, 2008-2012

Técnica mista

Fonte: $34^{a}$ Bienal de São Paulo
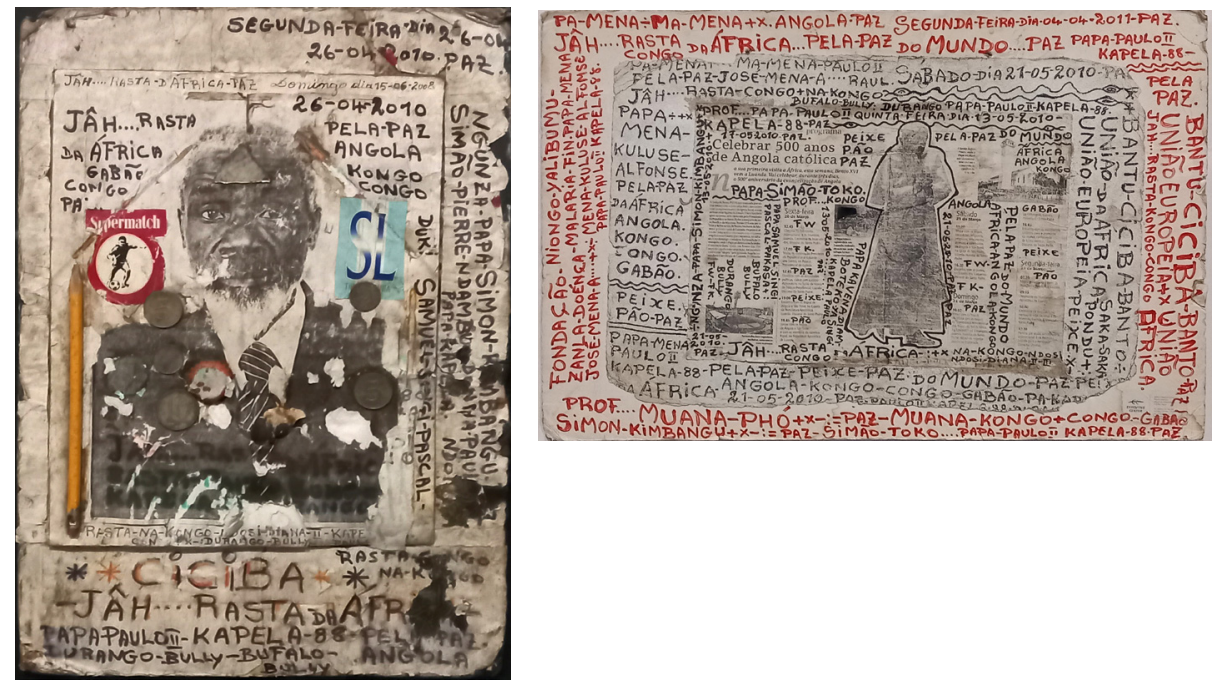
A terceira obra a ressaltar é Carta ao Velho Mundo de Jaider Esbell, nascido em 1979 em Roraima e falecido em novembro de 2021, em São Paulo, quando a Bienal está ainda em cartaz, bem como a mostra Moqúem Surarî: arte indígena contemporânea, sob sua curadoria, no Museu de Arte Moderna. Jaider também expunha nesta Bienal, uma série de pinturas relacionadas ao universo indígena contextualizando mitologia com os conflitos de terra contemporâneos vividos pelo povo Macuxi.

Jaider era artista e escritor e tinha um papel central no movimento de consolidação da Arte Indígena contemporânea no contexto brasileiro atuando também como curador, educador, ativista, promotor e catalizador cultural.

Carta ao Velho Mundo é uma obra realizada em 2018-2019. É composta por anotações e desenhos sobre cada página de um livro de 400 páginas com textos e reproduções de pinturas europeias comprada pelo artista em um sebo. A obra denuncia séculos de colonização eurocêntrica sobre o que é arte (GALERIA JAIDER ESBELL, 2020).

Figura 7. Jaider Eisbell. Página de Carta ao velho mundo, 2021 Livro digitalizado impresso Fonte: $34^{\mathrm{a}}$ Bienal de São Paulo Foto: Gisela Belluzzo

Figura 8. Jaider Eisbell. Página de Carta ao velho mundo, 2021 Livro digitalizado impresso Fonte: $34^{a}$ Bienal de São Paulo Foto: Gisela Belluzzo
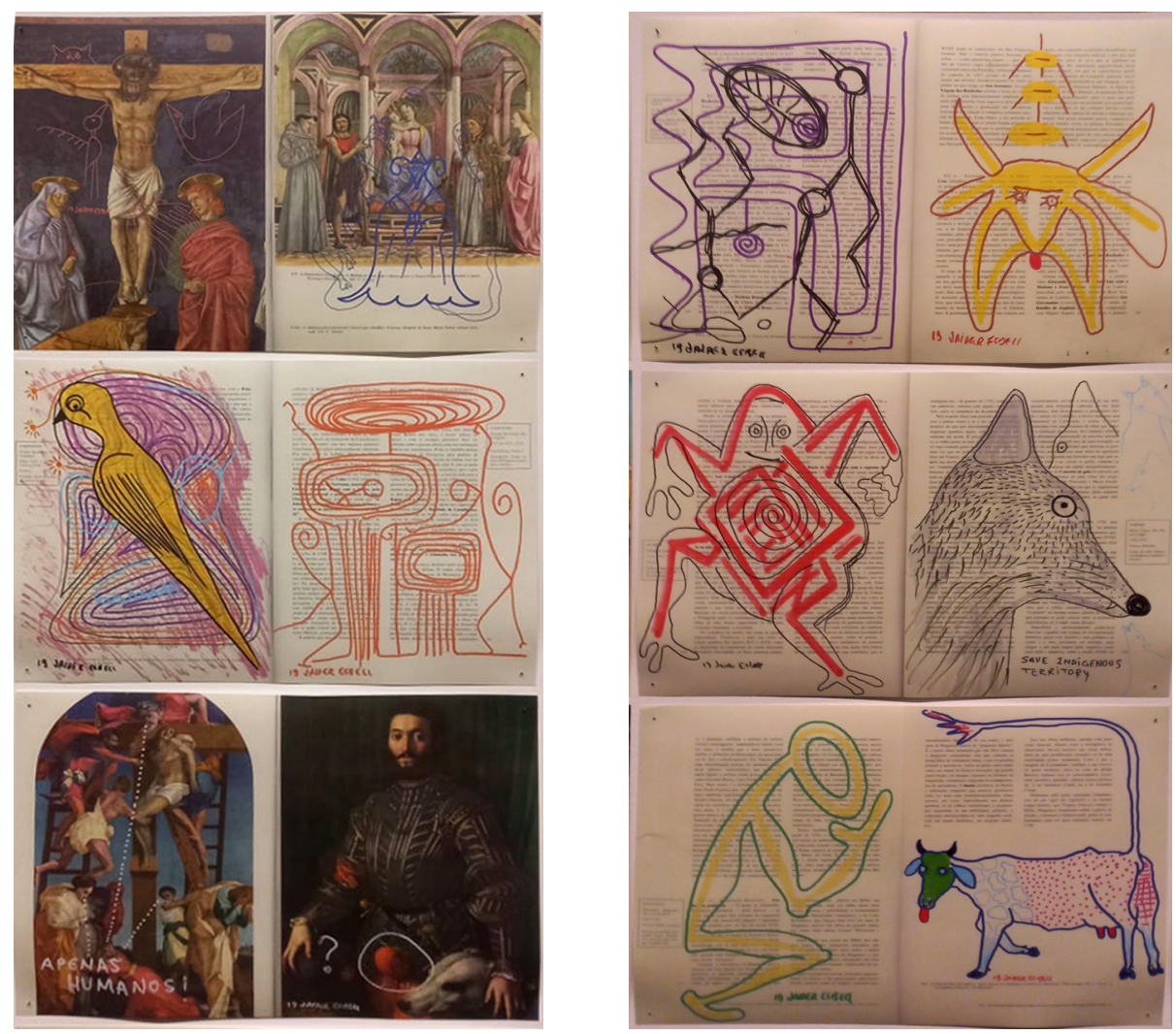

\section{Manuscritos e manualidades}

\section{Caligrafias}

A caligrafia tem uma força expressiva ao trazer a marca do gesto do indivíduo, é um signo do corpo, uma assinatura do sujeito. A caligrafia traz também a vivacidade e o entusiasmo do espontâneo, do tempo particular 
e único de cada mão ao fazer cada linha ou traço. Em termos semióticos, a escrita manual é o índice - a marca do gesto, e contém o ícone - a possibilidade de captura do instante, do único, daquele momento particular, ambos contidos no símbolo e, como tal, tem o poder de evocar o singular e o surpreendente em uma mensagem em linguagem convencional - a escrita.

A escrita manual ou caligrafia traz várias marcas significativas que a máquina de escrever ou o texto digitalizado não revelam. Pode representar, em alguns casos, a força do vernacular, daquilo que é próprio de uma região ou cultura. Talvez por isso, nestes tempos globalizados, nos quais, por um lado, busca-se uma homogeneização, e por outro, acentuam-se as diferenças, a caligrafia e a escrita manual apareçam com força, não por acaso, nesta e em outras mostras, com uma representatividade de obras de artistas cujas vozes se manifestam com essas formas, ao contrário da impessoalidade da tecnologia e da digitalidade. Escritas feitas à mão são expressivas e trazem a marca de uma autoria, seja esta autoria representativa de um indivíduo ou grupo.

\section{Desenhos}

Existem vários tipos de desenhos. Este que está presente nessas obras, tem uma forma de ser aberta e explícita, mesmo que demande um tempo para penetrá-lo; pelo traço que é nítido, ainda que hesitante, pela linha que corre trêmula ou segura. Mesmo que tenha áreas preenchidas com cores o faz de modo diferente de uma pintura. Quando se desenha este tipo de desenho, mais livre, por assim dizer, não existem muitas mediações, são poucas, apenas o lápis ou a caneta. Assim, o desenho é uma expressão direta e destemida. Ele também traz a descoberta daquele que desenha a respeito de si mesmo e do mundo que está vendo e revelando a seu modo, e oferece o desvendamento do desenhador e do mundo aos olhos do outro.

Barbosa (2015, p.13) traz algumas definições de desenho do educador Eduardo Veras que tomarei aqui emprestadas:

"O desenho é um dos instrumentos mais caros para a anotação daquela ideia que irrompe de imediato, urgente, como se brotasse de repente, do nada; “"

"O desenho - generoso - se presta a gestos díspares, à primeira vista contraditórios";

"O desenho funda novas realidades".

Sim, o desenho mais espontâneo pode ser feito com canetinhas sobre superfícies que permitem a passagem dos gestos diretamente ao computador. Mas no caso dos exemplos dessas obras eles estão sobre papel e essa materialidade também é significativa neste contexto.

\section{Cartas}

De maneira geral, cartas são escritas para serem lidas de modo individual e em silêncio. Propõem uma comunicação especial do(s) remeten- 
te(s) com o(s) destinatário(s). Uma carta sempre tem um caráter particular, mesmo que seja uma carta aberta, publicada e disponível para muitos.

Ao discorrer sobre a carta, Flusser (2010, p.158-161), ressalta que: "[...] cartas são coisas que se esperam - ou chegam inesperadamente. Naturalmente, esperar é uma categoria religiosa: significa ter esperança". Em outros trechos, o autor escreve, a carta:

[...] é um dos poucos elementos solenes que ainda possuímos [...] e [...] como tudo que é solene, as cartas também seguem determinados rituais, [...] no modo como são colocados os endereços, no tratamento formal, nas palavras finais [...] a escrita de cartas tem relação com o fazer literário [...] oscila entre o classicismo e o romantismo [...] pode ser considerada uma das artes mais refinadas. É compreendida como se estivesse em decadência. (FLUSSER, 2010, 158-161).

Certamente essa observação constata o definhamento dessa forma de comunicação em um momento tão pouco afeito a delicadezas desse tipo. Cartas tem esse sentido saudosista, fora de moda, como outras formas refinadas e solenes de comunicação. Mais adiante no texto, o filósofo faz uma outra observação importante ao ressaltar que a carta busca reconhecer o remetente e, como tal, na carta não há tanta influência do meio, do mediador, que poderá intervir com sua presença, com sua marca e matéria. A carta pressupõe uma relação intersubjetiva, um segredo e guarda um certo mistério. Quando exposta publicamente, como no caso dessa mostra Bienal, emociona pela delicadeza, pelo gesto exposto, pela singularidade da mensagem e pela fragilidade do papel. Nem mesmo é preciso ler o que está escrito para admirá-la, é um documento visual de extrema beleza.

"Cartas são escritos que não querem ser publicados", escreve Flusser (2010, p.168). As cartas que constituem essas obras contrastam com outras formas de expor a intimidade neste momento contemporâneo.

\footnotetext{
A luz profana do iluminismo público penetra em tudo o que está cifrado e lacrado porque a caverna do mistério ganhou fendas. Aquilo que é público, o público, o impessoal rasgou seus direitos a tudo o que for privado, escuro, não esclarecido. (FLUSSER, 2010, p.165).
}

Em tempos nos quais o valor de exposição atinge seu ápice e faz multiplicar gestos banais (e irritantes), esses traçados confidenciais, particulares, ressoam como lembranças de outros tempos, nos quais havia um respeito ao resguardo, à interioridade, à intimidade, à privacidade e à diferença.

Manual e materialidade

Santaella e Nöth (1997), classificam a evolução ou transformação da imagem em três paradigmas. $O$ primeiro, que os autores denominam 
pré-fotográfico refere-se a todas as imagens produzidas artesanalmente, feitas a mão. Os autores analisam esse tipo de imagem em diversos aspectos e ângulos e ressaltam que, quanto ao meio de produção, na imagem artesanal e manual, seja ela escrita ou desenhada "[...] fundem-se, num gesto indissociável, o sujeito que a cria, o objeto criado e a fonte de criação" (SANTAELLA; NÖTH, 1997, p. 164). Significa que é um objeto único, e como tal, autêntico e solene. Os autores enfatizam que esse tipo de prática se destaca - quanto ao seu agente produtor - pela imaginação, pelo olhar do sujeito para a figuração e pela capacidade de figurar o visível e o invisível. Em relação ao papel do receptor, esta imagem é feita para contemplação e,

[...]convida o receptor a um impossível contato imediato sem mediações, ao mesmo tempo que produz um afastamento que é próprio dos objetos únicos, envolvidos no círculo mágico da aura da autenticidade como já foi teorizado por Walter Benjamin (SANTAELLA; NÖTH, 1997, p.164).

A materialidade se distingue pela corporeidade das coisas.

\begin{abstract}
Mesmo que o artefato tenha seu uso modificado ou sua operação prejudicada, a materialidade sugere um potencial de retorno à condição primeira, nem que seja apenas um conceito. A partir de meia dúzia de cacos de louça, o arqueólogo reconstitui mentalmente como teria sido o prato original (CARDOSO, 2013, p.152).
\end{abstract}

Tempo

Um outro aspecto que se apresenta nesta relação entre o manual e o digital, é a questão do tempo que pode ser destrinchada em algumas perspectivas. Uma delas é relativa ao tempo que se leva para ler esses escritos, incluindo a decifração da caligrafia intrincada e pessoal. Esta perspectiva solicita um tempo-contemplação que permita uma assimilação passo a passo, de degustação, de concentração e de retenção da atenção sobre aquela imagem. Outro entendimento sobre o tempo é no seu sentido histórico, um tempo rememorado e trazido à baila, um tempo outro, um tempo antigo, um pouco esquecido, nestes tempos atuais marcados pela aceleração e pelos consequentes apagamentos e esquecimentos de fatos e acontecimentos, logo substituídos por outros fatos e acontecimentos, facilitados pela tecnologia e pela vida digital. o tempo sugerido pela manualidade é contrário à lógica do consumo que permeia todos os aspectos da vida pessoal e social na contemporaneidade. Cardoso (2013, p.154) observa, com a lucidez do historiador: "A rápida evolução da tecnologia informática torna cada vez mais comum a experiência de achar insuficiente e ultrapassado aquilo que há muito tempo, era objeto de desejo e sonho de consumo". 


\section{Considerações finais}

Santos (2007 p.71), coloca que "o pensamento moderno ocidental é um pensamento abissal", constituído de uma linha divisória profunda e descomunal, e que divide a realidade social em "deste lado da linha" e "do outro lado da linha". Segundo o autor:

[...] a divisão é tal que "o outro lado da linha" desaparece como realidade, torna-se inexistente e é mesmo produzido como inexistente. Inexistência significa não existir sob qualquer modo de ser relevante ou compreensível. Tudo aquilo que é produzido como inexistente é excluído de forma radical porque permanece exterior ao universo que a própria concepção de inclusão considera como "o outro" (SANTOS, 2007, p. 71).

Segundo o autor, no sistema mundial contemporâneo, subsistem estruturalmente, as linhas cartográficas "abissais" que fundamentavam o pensamento moderno ocidental, formatando relações políticas e culturais excludentes. Associada à injustiça global encontra-se a injustiça cognitiva global (SANTOS, 2007, p.71).

A questão da colonização atinge certamente o campo das artes. Felizmente, tem crescido os debates em torno da questão, como mostra o protagonismo de Eisball na 34 $4^{a}$ Bienal de São Paulo. A questão de um retorno aos procedimentos manuais tem também crescido por diversas razões, desde a falta de acesso a estas tecnologias, até a questão da impessoalidade das técnicas digitais, passando, sem dúvida, pela dominação mercadológica da tecnologia digital em detrimento de posicionamentos culturais inclusivos.

Um aspecto crucial desta $34^{\mathrm{a}}$ Bienal, é a quantidade de documentos, fragmentos, traços de sensibilidades expostas e de obras em processo. Caminhos possíveis, com falhas e hesitações, inconclusos e inconclusivos, distantes muitas vezes, da ideia de obra de arte acabada e de "último grito" em termos de exposição de arte. Essas e outras obras, trazem para o ambiente artístico essa ideia de incompletude por meios dos quais também podemos tecer nossas relações e ir revivendo e (re)construindo histórias, nossas e de outros, algumas esquecidas e consideradas obsoletas. A força dessas obras permite essas associações. 


\section{Referências}

BARBOSA, Ana Mae. Redesenhando o desenho. Educadores, políticas e histórias. Cortez: São Paulo, 2015.

CARDOSO, Rafael. Design para um mundo complexo. São Paulo: Cosac Naify, 2012.

FLUSSER, Vilém. O universo das imagens técnicas. Elogio da superficialidade. São Paulo: Annablume, 2008.

FLUSSER, Vilém. A Escrita: há futuro para a escrita? Trad. Murilo Jardelino da Costa. São Paulo: Annablume, 2010.

GALERIA JAIDER EISBELL, 2020. Disponível em http://www.jaideresbell.com.br/site/sobre-o-artista/ Acesso em 10 de nov. de 2021

Germano, Beta. Faleceu o artista angolano Paulo Kapela, 2020. Disponível em https:// www.artequeacontece.com.br/faleceu-o-artista-angolano-paulo-kapela Acesso em 02 de nov. de 2021 ARTEQUEACONTECE

KIFFER, Ana. Corte/Relação: Antonin Artaud e Édouard Glissant. In OSE, Elvira Dyangani. (editora); 34를 Bienal de São Paulo: Faz escuro mas eu canto: catálogo. Vários autores. São Paulo: Bienal de São Paulo, 2021.

OSE, Elvira Dyangani. (editora); 34 ${ }^{\mathrm{a}}$ Bienal de São Paulo: Faz escuro mas eu canto: catálogo. Vários autores. São Paulo: Bienal de São Paulo, 2021.

SANTAELLA, Lúcia; NÖTH, Winfried. Imagem, cognição, semiótica, mídia. São Paulo: Iluminuras, 1997.

SANTOS, Boaventura de Souza. Para além do pensamento abissal. Das linhas globais a uma ecologia de saberes. São Paulo: Novos Estudos CEBRAP n. 79, novembro de 2007, pp. $71-94$

34 Bienal de São Paulo. Disponível em ttp://34.bienal.org.br/sobrea34?utm_source=Google\&utm_medium=Search\&utm_campaign=34_Bienal\&utm_content=34_Bienal Acesso em 03 de nov.de 2021 